\title{
ANALISIS HUBUNGAN PENGGUNAAN MEDIA SOSIAL TERHADAP INOVASI PENGEMBANGAN BISNIS DI MASA PANDEMI CORONAVIRUS DISEASE - 19
}

\author{
Syehvira Shal Shabilla ${ }^{1}$, Diah Puspita Ningrum² ${ }^{2}$ Ayuning Dwis Cahyasari ${ }^{3}$, \\ Siti Maghfirotul Ulyah ${ }^{4} *$ \\ 1, 2, 3,4 Program Studi Statistika, Jurusan Matematika, Fakultas Sains dan \\ Teknologi, Universitas Airlangga, Indonesia \\ syehvira.al.abilla-2019@ fst.unair.ac.id ${ }^{1}$, diah.puspita.ningrum- \\ 2018@fst.unair.ac.id ${ }^{2}$, ayuning.dwis.cahyasari-2019@fst.unair.ac.id ${ }^{3}$, \\ maghfirotul.ulyah@fst.unair.ac.id*4 \\ *Corresponding Author
}

Received 03 November 2021; revised 23 December 2021; accepted 25 December 2021.

\begin{abstract}
ABSTRAK
Data Badan Pusat Statistik (BPS) pada triwulan III tahun 2020 menyatakan bahwa perekonomian Indonesia mengalami resesi dengan pertumbuhan sebesar $-3,49$ persen. Hal ini mengartikan bahwa pandemi Coronavirus Disease (Covid-19) berdampak pada kondisi ekonomi di Indonesia. Dalam laporan World Economic Forum (WEF) menunjukkan bahwa nilai terendah Indonesia terletak pada indikator kemampuan inovasi sebesar 37.7 tepatnya di peringkat ke-74. Hal ini dapat mengganggu salah satu tujuan Sustainable Development Goals (SDGs) yaitu menjaga kestabilan pertumbuhan ekonomi yang salah satunya bagi negara berkembang seperti Indonesia. Namun, survei Katadata Insight Center (KIC) menyatakan bahwa marketplace membantu pebisnis di masa pandemi. Berdasarkan hal tersebut penelitian ini dilakukan untuk mengetahui hubungan media sosial terhadap inovasi pengembangan bisnis dalam membantu perekonomian di masa pandemi Covid-19 yang diuji dengan analisis statistika deskriptif dan uji Wilcoxon. Analisis statistika deskriptif bertujuan untuk memberikan gambaran dari hasil survei terkait penggunaan sosial media dan inovasi dalam berbisnis berdasarkan nilai maksimum dan minimum. Uji Wilcoxon dilakukan untuk menganalisis perbedaan pendapatan rata - rata baik sebelum dan selama pandemi serta sebelum dan sesudah pelaku bisnis melakukan inovasi untuk mengembangkan bisnisnya di masa pandemi. Hasil analisis menunjukkan bahwa terdapat perbedaan pendapat baik sebelum dan selama pandemi maupun sebelum dan sesudah berinovasi. Hal ini mengindikasikan bahwa dengan adanya keterkaitan sosial media terhadap inovasi pengembangan bisnis dapat membantu perekonomian di masa pandemi Covid-19 berbasis digital yang nantinya dapat dijadikan acuan pemerintah dalam meningkatkan sektor ekonomi.
\end{abstract}


Kata kunci: analisis statistika deskriptif, inovasi pengembangan bisnis, media sosial, pertumbuhan ekonomi, uji wilcoxon

\begin{abstract}
Data from the Central Bureau of Statistics in the third quarter of 2020 stated that the Indonesian economy experienced a recession with a growth of -3.49 percent. This means that the Coronavirus Disease (Covid-19) pandemic has an impact on economic conditions in Indonesia. The World Economic Forum (WEF) report shows that Indonesia's lowest score lies in the innovation capability indicator of 37.7 , to be precise, at 74th. This can interfere with one of the Sustainable Development Goals (SDGs) goals, namely maintaining stable economic growth, one of which is for developing countries such as Indonesia. However, the Katadata Insight Center (KIC) survey stated that the market place helps businesses during the pandemic. Based on this, this study was conducted to determine the relationship of social media to business development innovation in helping the economy during the Covid-19 pandemic which was tested by descriptive statistical analysis and the $\mathrm{T}$ test. Descriptive statistical analysis aims to provide an overview of the survey results related to the use of social media and innovation. In doing business based on maximum and minimum values. The Wilcoxon-test was conducted to analyze the difference in average income both before and during the pandemic as well as before and after innovating. The results of the analysis show that there are differences of opinion both before and during the pandemic as well as before and after innovating. This indicates that the existence of social media links to business development innovation can help the economy during the digital-based Covid-19 pandemic which can later be used as a reference for the government in improving the economic sector.
\end{abstract}

Keywords: descriptive statistical analysis, business development innovation, social media, economic growth, wilcoxon test

\title{
PENDAHULUAN
}

Dampak dari adanya pandemi Coronavirus Disease (Covid-19) menyebabkan terjadinya kontraksi ekonomi secara global, termasuk di negara Indonesia. Berdasarkan data dari International Monetary Fund (IMF) tahun 2020, pertumbuhan ekonomi dunia diproyeksikan terkontraksi sebesar -3,0 persen (Arianto, 2020). Badan Pusat Statistik (BPS) (2019) juga mencatat bahwa pertumbuhan ekonomi Indonesia triwulan III sebesar 5,02 persen di tahun 2019 lebih rendah dari pencapaian tahun 2018. Bahkan, pada triwulan III-2020 Indonesia resmi mengalami resesi dengan pertumbuhan sebesar -3,49 persen (BPS, 2020). Rendahnya pertumbuhan ekonomi tersebut, menjadi tantangan bagi Indonesia 
untuk bisa tumbuh positif walaupun cukup kecil pertumbuhannya di masa yang sulit seperti saat ini. Apalagi dalam laporan World Economic Forum (WEF) menunjukkan bahwa nilai terendah Indonesia terletak pada indikator kemampuan inovasi sebesar 37,7 tepatnya di peringkat ke-74 (WEF, 2019). Disamping rendahnya ekonomi, sumber pertumbuhan ekonomi Indonesia pada triwulan 12020 terbesar pada sektor informasi dan komunikasi sebesar 0,53 persen (Jatmiko, 2020).

Tidak hanya pada aspek ekonomi, pandemi Covid-19 juga telah mengubah cara hidup masyarakat dengan adanya anjuran physical distancing. Adanya jaga jarak membuat sebagian besar aktivitas ekonomi berubah dari tatap muka menjadi online yang minim interaksi. Hal ini menyebabkan kegiatan secara elektronik meningkat melalui media sosial. Media sosial tidak hanya sekedar sarana atau wadah berkomunikasi jarak jauh saja, kini media sosial juga dijadikan pemasaran digital dalam rangka penyesuaian diri atas pembatasan kegiatan yang terjadi. Hal ini dibuktikan dari survei Katadata Insight Center (KIC), yang menyasar 392 pelaku UMKM di sejumlah kota di Indonesia dan Surabaya menjadi salah satu wilayah yang dijadikan responden. Hasil dari survei menunjukkan bahwa UMKM yang berjualan offline akhirnya memilih berjualan online. Bahkan sebanyak $77 \%$ UMKM menyatakan marketplace membantu mereka memasarkan produk, sehingga bisa bertahan dan berjualan di masa pandemi (Burhan, 2021). Selain itu dari survei Search Engine Advertising (SEA) Insight terhadap 2200 pelaku usaha di Indonesia menunjukkan bahwa sekitar 50\% pelaku usaha mengalami peningkatan penggunaan media digital seperti, media sosial dan e-commerce (SEA, 2020).

Inovasi bisnis merupakan hal yang mutlak dilakukan dalam dunia bisnis. Inovasi dapat diartikan sebagai suatu proses tindakan untuk memperoleh gagasan baru dan penerapan nyata dalam praktik (Yunus, 2010). Dalam inovasi pemasaran ditandai oleh kemampuan wirausaha dalam memperkenalkan inovasi produk, promosi, dan saluran pemasaran. Penelitian yang berkaitan dengan media sosial terhadap inovasi pengembangan bisnis diantaranya adalah penelitian yang dilakukan oleh Rahayu \& Laela (2018), Sekolah Tinggi Ilmu Ekonomi IPWI Jakarta. Hasil dari penelitian tersebut menunjukan terdapat pengaruh variabel minat berwirausaha terhadap kewirausahaan pada mahasiswa dan terdapat pengaruh 
variabel penggunaan media sosial terhadap kewirausahaan pada mahasiswa. Penelitian lain yang berkaitan adalah oleh Alfaruk (2010), Pascasarjana Universitas Surabaya. Hasil dari penelitian tersebut menunjukkan bahwa secara parsial terdapat pengaruh pemanfaatan sosial media dan motivasi pada minat berwirausaha mahasiswa Fakultas Ekonomi Universitas Muhammadiyah Sidoarjo, serta tidak ada pengaruh signifikan pada pengetahuan kewirausahaan terhadap minat berwirausaha mahasiswa Fakultas Ekonomi Universitas Muhammadiyah Sidoarjo. Namun, secara simultan terdapat pengaruh pemanfaatan sosial media, motivasi dan pengetahuan mahasiswa terhadap minat berwirausaha mahasiswa fakultas Ekonomi Universitas Muhammadiyah Sidoarjo.

Berdasarkan fakta dan penelitian yang telah disebutkan di atas, perlu dilakukan penelitian untuk mengetahui keterkaitan sosial media terhadap inovasi pengembangan bisnis dalam membantu perekonomian di masa pandemi Covid-19. Selain itu, yang membedakan penelitian ini dengan penelitian serupa lainnya adalah digunakannya uji Wilcoxon untuk menganalisis perbedaan pendapatan rata - rata baik sebelum dan selama pandemi serta sebelum dan sesudah pelaku bisnis melakukan inovasi untuk mengembangkan bisnisnya di masa pandemi. Dengan demikian penelitian dapat memberikan kesimpulan apakah sosial media mampu menginovasi pelaku bisnis dalam meningkatkan perekonomiannya di masa pandemi Covid-19.

\section{METODE PENELITIAN}

Penelitian ini menggunakan data primer yang diperoleh dari pengisian kuesioner responden. Populasi penelitian ini merupakan seluruh pelaku bisnis, kemudian diambil sampel responden menggunakan teknik purposive sampling dengan ketentuan usia produktif yaitu 15 - 64 tahun dan bertempat tinggal pada daerah Kota Surabaya sebanyak 60 responden. Purposive sampling dipilih karena metode pengambilan sampel memerlukan kriteria-kriteria tertentu agar sampel yang diambil sesuai dengan tujuan penelitian. Pengambilan jumlah sampel berdasarkan pada pernyataan yang dikemukakan oleh Fraenkel dan Wallen (1993) yang menyarankan bahwa besar sampel minimum untuk penelitian korelasional sebanyak 50. N pernyataan tersebut maka peneliti merasa cukup karena teknik 
sampling yang digunakan sesuai dan jumlah sampel melampaui minimum sampel. Terdapat 3 variabel dalam penelitian ini yaitu, variabel identifikasi intensitas penggunaan media sosial, identifikasi inovasi pengembangan bisnis dan rata-rata pendapatan. Adapun instrumen pertanyaan untuk setiap variabel penelitian disajikan pada Tabel 1 dan Tabel 2 sebagai berikut:

Tabel 1. Instrumen Pertanyaan Identifikasi Intensitas Penggunaan Media Sosial

\begin{tabular}{|c|l|}
\hline Variabel & \multicolumn{1}{|c|}{ Identifikasi Intensitas Penggunaan Media Sosial } \\
\hline X1 & $\begin{array}{l}\text { Responden memiliki perangkat yang mendukung dalam berbisnis } \\
\text { online }\end{array}$ \\
\hline X2 & $\begin{array}{l}\text { Responden memiliki jaringan internet yang mendukung di } \\
\text { wilayahnya }\end{array}$ \\
\hline X3 & $\begin{array}{l}\text { Responden memiliki finansial (budget) yang cukup untuk memenuhi } \\
\text { kebutuhan kuota internet }\end{array}$ \\
\hline X5 & $\begin{array}{l}\text { Responden memiliki pengetahuan untuk menggunakan media sosial } \\
\text { dengan baik }\end{array}$ \\
\hline X6 & $\begin{array}{l}\text { Responden sering menggunakan sosial media untuk mencari tren } \\
\text { terbaru dan informasi-informasi lainnya terkait berbisnis di media } \\
\text { sosial } \\
\text { Responden aktif mengikuti akun bisnis yang berkaitan dengan bisnis } \\
\text { di media social }\end{array}$ \\
\hline X7 & $\begin{array}{l}\text { Responden aktif mengikuti grup mentoring yang berkaitan dengan } \\
\text { bisnis di media sosial }\end{array}$ \\
\hline X8 & $\begin{array}{l}\text { Responden aktif mengikuti grup diskusi bagi pemula bisnis online di } \\
\text { media sosial }\end{array}$ \\
\hline
\end{tabular}

Tabel 2. Instrumen Pertanyaan Identifikasi Inovasi Pengembangan Bisnis

\begin{tabular}{|c|c|}
\hline Variabel & Identifikasi Inovasi Pengembangan Bisnis \\
\hline $\mathrm{X} 1$ & Responden membuat atau menciptakan variasi produk baru \\
\hline $\mathrm{X} 2$ & Responden menambah variasi pilihan rasa baru \\
\hline $\mathrm{X} 3$ & Responden membuat produk dengan cara atau teknik baru \\
\hline $\mathrm{X} 4$ & Responden membuat iklan untuk produk yang saya buat \\
\hline $\mathrm{X} 5$ & $\begin{array}{l}\text { Responden memberikan ciri khas atau keunikan yang menarik } \\
\text { terhadap produk }\end{array}$ \\
\hline X6 & Responden membuat pendistribusian yang lebih luas dari sebelumnya \\
\hline $\mathrm{X} 7$ & Responden memberikan promosi pada saat penjualan produk \\
\hline $\mathrm{X} 8$ & $\begin{array}{l}\text { Responden memberikan kemasan yang aman dan menarik terhadap } \\
\text { produk }\end{array}$ \\
\hline
\end{tabular}


Pada penelitian ini menggunakan 2 metode analisis yaitu, analisis statistika deskriptif dan uji Wilcoxon. Analisis statistika deskriptif bertujuan untuk memberikan gambaran dari hasil survei terkait penggunaan sosial media dan inovasi dalam berbisnis berdasarkan nilai maksimum dan minimum. Uji Wilcoxon digunakan untuk mengetahui pengaruh bisnis yang didirikan dapat membantu kelancaran ekonomi selama masa pandemi Covid-19.

\section{HASIL PENELITIAN DAN PEMBAHASAN}

Suatu kuesioner dapat dikatakan valid apabila setiap butir pertanyaan yang diajukan memiliki keterkaitan yang tinggi. Sehingga peneliti melakukan uji validitas dan reliabilitas terhadap setiap pernyataan yang ada di dalam kuesioner. Berikut hasil uji validitas disajikan pada Tabel 3 dan uji reliabilitas disajikan pada Tabel 4.

Tabel 3. Hasil Uji Validitas Variabel Intensitas Penggunaan Media Sosial dan Variabel Inovasi Pengembangan Bisnis

\begin{tabular}{cccc}
\hline \multirow{2}{*}{ Variabel } & \multicolumn{3}{c}{ Identifikasi Intensitas Penggunaan Media Sosial } \\
\cline { 2 - 4 } & Nilai P-Value & Nilai r hitung & Kesimpulan \\
\hline X1 & 0,000 & 0,482 & Valid \\
X2 & 0,000 & 0,595 & Valid \\
X3 & 0,000 & 0,563 & Valid \\
X4 & 0,000 & 0,605 & Valid \\
X5 & 0,000 & 0,614 & Valid \\
X6 & 0,000 & 0,719 & Valid \\
X7 & 0,000 & 0,695 & Valid \\
X8 & 0,000 & 0,555 & Valid \\
\hline \multirow{2}{*}{ Variabel } & \multicolumn{4}{c}{ Identifikasi Inovasi Pengembangan Bisnis } \\
\cline { 2 - 4 } Nilai P-Value & Nilai r hitung & Kesimpulan \\
X1 & 0,000 & 0,699 & Valid \\
X2 & 0,000 & 0,646 & Valid \\
X3 & 0,000 & 0,721 & Valid \\
X4 & 0,000 & 0,534 & Valid \\
X5 & 0,000 & 0,774 & Valid \\
X6 & 0,000 & 0,488 & Valid \\
X7 & 0,000 & 0,609 & Valid \\
X8 & 0,000 & 0,702 & Valid \\
\hline
\end{tabular}

Berdasarkan hasil uji validitas pada Tabel 3, diperoleh nilai semua item pernyataan kedua variabel memiliki $p$-value sebesar 0,000 artinya kurang dari taraf signifikansi atau nilai $r$ hitung lebih besar dari $r$ tabel $(0,254)$ sehingga dapat 
dikatakan bahwa semua butir pertanyaan memiliki nilai $p$-value 0,000 , maka semua butir pertanyaan tersebut telah valid.

Selanjutnya pengujian reliabilitas yang dilakukan untuk mengetahui apakah butir pertanyaan yang diteliti menghasilkan ukuran yang relatif konstan jika diulang-ulang dengan menggunakan metode Alfa Cronbach. Berdasarkan uji reliabilitas yang dilakukan, diperoleh hasil yang ditunjukkan pada Tabel 4 .

Tabel 4. Hasil Uji Reliabilitas Variabel Intensitas Penggunaan Media Sosial dan Variabel Inovasi Pengembangan Bisnis

\begin{tabular}{ccc}
\hline Variabel & Nilai Cronbach Alfa & Kesimpulan \\
\hline $\begin{array}{c}\text { Identifikasi Intensitas Penggunaan Media } \\
\text { Sosial }\end{array}$ & 0,740 & Reliabel \\
$\begin{array}{c}\text { Identifikasi Inovasi Pengembangan } \\
\text { Bisnis }\end{array}$ & 0,795 & Reliabel \\
\hline
\end{tabular}

Berdasarkan hasil pengujian reliabilitas yang dilakukan, diperoleh nilai Cronbach Alfa sebesar 0,740 untuk variabel identifikasi intensitas penggunaan media sosial dan 0,795 untuk identifikasi inovasi pengembangan bisnis. Sehingga dapat dikatakan bahwa semua butir pertanyaan tersebut reliabel.

Selanjutnya, untuk mengetahui jumlah minimum dan maksimum dari sampel dibuat statistika deskriptif dalam bentuk grafik. Statistika deskriptif dari sampel disajikan pada Tabel 5, Tabel 6, Tabel 7, dan Tabel 8 sebagai berikut:

Tabel 5. Persentase Intensitas Penggunaan Media Sosial

\begin{tabular}{cc}
\hline Keterangan & Persentase \\
\hline$<10$ jam per bulan & $8 \%$ \\
$10-40$ jam per bulan & $35 \%$ \\
$>40$ jam per bulan & $57 \%$ \\
\hline
\end{tabular}

Tabel 6. Persentase Media Sosial yang Digunakan

\begin{tabular}{cc}
\hline Keterangan & Persentase \\
\hline Youtube & $13 \%$ \\
Instagram & $29 \%$ \\
Whatsapp & $22 \%$ \\
Tiktok & $13 \%$ \\
Twitter & $5 \%$ \\
Line & $4 \%$ \\
Tribelio & $1 \%$ \\
Facebook & $11 \%$ \\
\hline
\end{tabular}


Tabel 7. Persentase Tanggapan Responden Terkait Variabel Intensitas Penggunaan Media Sosial

\begin{tabular}{cc}
\hline Keterangan & Persentase \\
\hline Perangkat & $14 \%$ \\
Jaringan & $14 \%$ \\
Budget & $13 \%$ \\
Pengetahuan & $13 \%$ \\
Tren dan informasi & $14 \%$ \\
Follow akun bisnis & $13 \%$ \\
Join grup mentoring & $10 \%$ \\
Join grup diskusi & $9 \%$ \\
\hline
\end{tabular}

Tabel 8. Persentase Tanggapan Responden Terkait Variabel Inovasi Pengembangan Bisnis

\begin{tabular}{cc}
\hline Keterangan & Persentase \\
\hline Produk baru & $11 \%$ \\
Variasi produk & $12 \%$ \\
Pembaruan teknik & $11 \%$ \\
Iklan produk & $11 \%$ \\
Ciri khas produk & $14 \%$ \\
Distribusi yang luas & $12 \%$ \\
\hline
\end{tabular}

Dari Tabel 5, Tabel 6, Tabel 7, dan Tabel 8 diperoleh bahwa intensitas penggunaan media sosial paling banyak dalam rentang waktu > 40 jam per bulan. Intensitas penggunaan media sosial didukung dengan ketersediaan perangkat dan jaringan, selain itu penggunaan media sosial yang paling banyak digunakan adalah untuk mencari tren terbaru dan informasi lain terkait berbisnis di media sosial. Media sosial yang paling banyak digunakan responden untuk mencari informasi terkait dunia bisnis adalah Instagram. Pada inovasi pengembangan bisnis, menunjukan hasil yang paling banyak dilakukan adalah inovasi pada strategi promosi saat penjualan produk, inovasi dengan memberikan ciri khas atau keunikan pada produk, dan inovasi pada kemasan sehingga produk aman dan menjadi lebih menarik.

Selanjutnya dilakukan analisis statistika deskriptif pada data rata-rata pendapatan pelaku bisnis online sebelum dan sesudah berinovasi serta selama pandemi dan saat pandemi yang tersaji pada Gambar 1 sebagai berikut: 


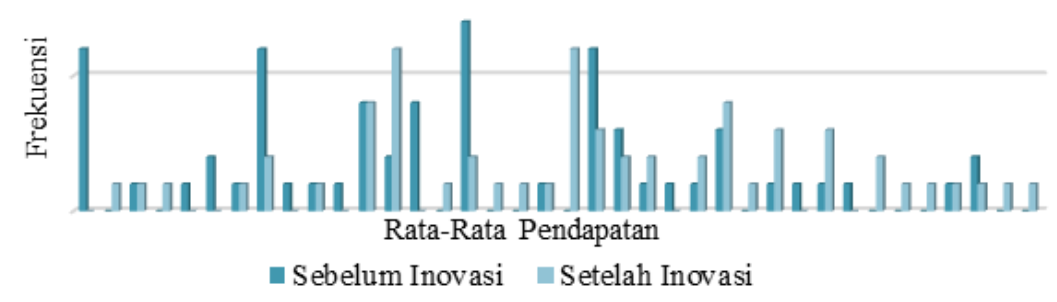

(a)

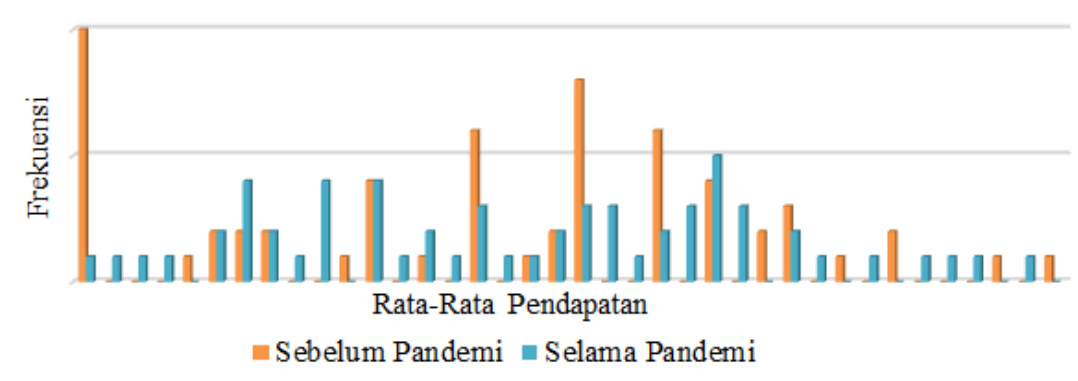

(b)

Gambar 1. (a) Rata - Rata Penghasilan Sebelum dan Selama Pandemi (b) Rata - Rata Penghasilan Sebelum dan Setelah Berinovasi

Berdasarkan Gambar 1. menunjukkan bahwa rata-rata pendapatan pelaku bisnis online cenderung mengalami penurunan selama pandemi, namun sebaliknya setelah melakukan inovasi rata-rata pendapatan para pelaku bisnis online cenderung mengalami kenaikan. Selanjutnya dilakukan uji Wilcoxon berpasangan untuk mengetahui apakah terdapat perbedaan rata-rata pendapatan sebelum dan selama pandemi serta sebelum dan setelah inovasi. Pengujian ini dilakukan dengan bantuan software SPSS, hasilnya disajikan dalam Tabel 7. sebagai berikut:

Tabel 9. Hasil Pengujian Wilxocon dengan SPSS

\begin{tabular}{lr}
\hline \multicolumn{1}{c}{ Variabel } & $p$-value \\
\hline Sebelum pandemi dan Saat pandemi & 0,000 \\
Sebelum berinovasi dan sesudah berinovasi & 0,000 \\
\hline
\end{tabular}

Berdasarkan perolehan Tabel 9, diperoleh hasil p-value baik variabel sebelum pandemi dan Saat pandemi serta sebelum berinovasi dan sesudah berinovasi mempunyai nilai sebesar 0,000. Dengan menggunakan nilai alpha sebesar 0,1 pada data terkait ekonomi (Silalahi et al, 2015), dapat ditarik kesimpulan bahwa terdapat perbedaan rata-rata penghasilan baik itu sebelum dan 
sesudah pandemi maupun sebelum dan sesudah berinovasi karena nilai $p$-value lebih kecil daripada alpha. Artinya, terdapat pengaruh rata-rata pendapatan sebelum dan selama pandemi serta sebelum dan setelah inovasi. Hal ini mengindikasikan bahwa dengan adanya keterkaitan sosial media terhadap inovasi pengembangan bisnis dapat membantu perekonomian di masa pandemi Covid-19. Hal ini relevan dengan hasil penelitian serupa sebelumnya, dimana pemanfaatan sosial media dapat berpengaruh terhadap kegiatan yang mampu mengembangkan bisnis. Tidak hanya berpengaruh pada minat dan motivasi dalam berwirausaha saja, namun juga berpengaruh pada kemampuan inovasi dalam rangka mengembangkan bisnis yang dijalani.

\section{SIMPULAN}

Berdasarkan analisis statistik deskriptif diperoleh hasil untuk variabel media sosial yang paling banyak digunakan responden untuk mencari informasi terkait dunia bisnis adalah Instagram. Sedangkan variabel untuk menunjukkan bahwa inovasi pengembangan bisnis yang paling banyak dilakukan adalah inovasi pada strategi promosi saat penjualan produk, inovasi dengan memberikan ciri khas atau keunikan pada produk, dan inovasi pada kemasan sehingga produk. Berdasarkan pengujian Wilcoxon diperoleh hasil bahwa terdapat perbedaan rata-rata penghasilan baik itu sebelum dan sesudah pandemi maupun sebelum dan sesudah berinovasi. Hal ini mengindikasikan bahwa dengan adanya keterkaitan sosial media terhadap inovasi pengembangan bisnis dapat membantu perekonomian di masa pandemi Covid-19. Pada penelitian ini diharap dapat membantu pihak terkait dalam menjaga kestabilan pertumbuhan ekonomi salah satunya bagi negara berkembang seperti Indonesia.

\section{UCAPAN TERIMA KASIH}

Para penulis mengucapkan terima kasih kepada Kementerian Pendidikan, Kebudayaan, Riset, dan Teknologi yang telah mendanai Program Kreativitas Mahasiswa 2021 dan Fakultas Sains dan Teknologi Universitas Airlangga yang telah mendukung penelitian ini. 


\section{DAFTAR PUSTAKA}

Arianto, B. (2020). Dampak pandemi COVID-19 terhadap perekonomian dunia. Jurnal Ekonomi Perjuangan, 2(2), 212-224.

Alfaruk, M. H. (2017). Pengaruh pemanfaatan sosial media, motivasi dan pengetahuan terhadap minat berwirausaha pada mahasiswa ekonomi di Universitas Muhammadiyah Sidoarjo. Jurnal Ekonomi Pendidikan dan Kewirausahaan, 4(2), 164-172.

Badan Pusat Statistik. (2019). Berita resmi statistik No. 89/11/Th.XXII, 5 November 2019 tentang pertumbuhan ekonomi indonesia triwulan III-2019. Jakarta: BPS.

Badan Pusat Statistik. (2020). Berita resmi statistik No. 85/11/Th.XXII, 5 November 2020 tentang pertumbuhan ekonomi indonesia triwulan III-2020. Jakarta: BPS.

Burhan, F. A. (2021). Survei KIC: mayoritas UMKM berdagang online di shopee dan tokopedia. URL: https://katadata.co.id/yuliawati/digital/608fc9fd30 bac/survei-kic-mayoritas-umkm-berdagang-online-di-shopee-dantokopedia. Diakses tanggal 30 Juni 2021.

Jatmiko, B, P. (2020). Perekonomian Indonesia pasca-pandemi covid-19. URL: https://money.kompas.com/read/2020/05/10/091500226/perekonomian-ind onesia-pasca-pandemi-covid-19?page=all. Diakses tanggal 19 November 2020.

SEA. (2020). Revitalisasi UMKM Indonesia. URL: https://cdn.sea.com/webmain/static/resource/seagroup/sea\%20insights/\%B 2020-0706\%5D\%20Indonesian\%20SME\%20Recovery\%20Report\%2020 20/Indonesian\%20SME\%20Recovery\%20Report\%20\%5BIDN\%5D.pdf.

Diakses tanggal 20 Juni 2021.

Silalahi, U., \& Atif, N. F. (2015). Metode penelitian sosial kuantitatif. Bandung: Universitas Katolik Parahyangan.

Rahayu, E. S., \& Laela, S. 2018. Pengaruh minat berwirausaha dan penggunaan sosial media terhadap kewirausahaan mahasiswa. Jurnal Pengembangan Wiraswasta, 20(3), 203-216.

WEF. (2019). The global competitiveness report 2019. Jenewa: WEF.

Yunus, M. (2010). Inovasi dan kreativitas dalam pemasaran. Malang: UIN Maliki Pres. 